\title{
Information Technology Capability and Its Impact on Firms Performance
}

\author{
Lejla Turulja, Nijaz Bajgorić \\ School of Economics and Business Sarajevo, Bosnia and Herzegovina
}

\begin{abstract}
According to the resource-based view, sources of competitive advantage begin with the notion that differences in performance are fundamentally due to the distinctive resources and capabilities that are valuable, rare, inimitable and nonsubstitutable (Barney, 2007; Wu et al., 2006). Information technology (IT) as a resource of the company has the increasing importance for the researches and managers. Research on the IT value within organizations and firms' IT capabilities have expanded over the past decade (Pérez-López et. al., 2012). Tippins and Sohi (2003) in their study defined IT capability as the existence of IT infrastructure, IT knowledge and IT operations within company. The purpose of this paper is to analyze the impact of IT capability on firms' innovativeness and the relationship among IT capability, firms' innovativeness and business performance. The study uses survey data from managers and structural equation modelling to assess the relationships between IT capability, firms' innovativeness and business performance.

This study finds that both IT capability and innovation capability play important role in achieving greater business performance. The findings indicate that managers should focus on development of the IT function within company, taking into account importance of IT investment as well as IT knowledge, and promotion of innovativeness.
\end{abstract}

Keywords: Information Technology Capability, Innovation, Innovativeness, Resource Based Theory, Performance, Dynamic Resource View

JEL classification: M15

\section{Introduction}

Many scholars have tried to answer the question "Why do some firms persistently outperform others?" (Barney et. al., 2007). One of the approaches to answering this question began to dominate this discussion and it focused on what were known as a firm's distinctive competencies and capabilities. Barney \& Clark (2007) stated that "distinctive competencies are those attributes of a firm that enable it to pursue a strategy more efficiently and effectively than other firms". This discussion led to the development of the several theories and approaches of which one of the most prominent is resource based theory (Wernerfelt, 1984; Barney, 1991).

Resource based theory (RBV) suggests that resources enable achievement of competitive advantage. Barney (1991) has identified four characteristics of resources essential for gaining sustainable competitive advantage, namely, value, rarity, imperfect imitability, and organized to capture value, known as the VRIO framework. Barney et. al. (2007) classified firm resources into four categories: physical capital resources, financial capital resources, human capital resources and organizational capital resources. In the age of globalization and intense competition, one of the most important resource is information technology (IT) used in a firm, which is a part of physical capital resources. IT is a generic term that refers 
to programs, computers and telecommunications while IT capability is a broader term and refers to the use of these technologies in order to meet the information needs of the company (Chakravarty et al., 2013; Mithas et al., 2011). Also, globalization pressures and rapid technology advances increase the need for firms to continuously adapt, improve, and innovate. Firms with greater innovativeness will be more successful in responding to changing environments and developing new capacities to achieve better performance (Chen et al., 2011).

The purpose of this paper is to analyze the impact of IT capability on firms' innovativeness and the relationship among IT capability, firms' innovativeness and business performance.

This paper is structured as follows. First, we analyze the concepts of IT capability and innovativeness. We then propose and test hypotheses about the relations between IT capability, innovativeness and firm performance. Finally, we discuss our findings and implications as well as give suggestions for future research.

\section{Literature Review}

\section{Information Technology Capability}

Considering the growing importance of information in today's business environment, achieving competence and capability with regard to the tools and processes used to manage information has taken on a new urgency. This capability is known as IT capability. Most of the papers, analyzing IT capabilities, focus on IT infrastructure and IT skills necessary to exploit the potential of information technology (Chakravarty et al., 2013). Based on it, firms' IT capability can be defined as the ability of firm to selects, accepts, configures and implements information technology. In other words, IT capability includes IT infrastructure within the company, as well as the supporting processes and knowledge related to it.

In this paper, we will use conceptualization of IT capability done by Pérez-López and Alegre (2012). In the mentioned study, IT capability is seen as a construct or a concept made up of three dimensions:

- IT knowledge is a degree to which the organization understands the capabilities of existing and emerging IT, or how organization is aware of IT possibilities (Pérez-López et. al., 2012).

- IT operations stand for the extent to which the firm uses IT to improve its business effectiveness, or possession of the IT-related methods, processes and techniques.

- IT infrastructure includes hardware, software and support staff, or tools and resources that contribute to the acquisition, processing, storage, dissemination and use of information (Pérez-López et. al., 2012).

Taken together, these three dimensions of IT capability interact and impact the degree to which an organization can leverage its investments in IT for strategic gains (Crawford et al., 2011).

\section{Innovativeness/Innovative capability}

Innovativeness is perceived as "exploring something new that has not existed before" (Dibrell et. al, 2014). Hurley and Hult (1998) defined innovativeness as "the notion of openness to new ideas as an aspect of a firm's culture." Innovative capability refers to the ability of a firm to develop new elements or a new combination of already known elements in products, processes, technologies, or management. As a result of innovativeness or innovative capabilities, firms generate different levels of innovations. Innovations can be classified in four categories: 
product innovation, process innovation, organization or management innovation, marketing innovation (Lee \& Tsai, 2005).

\section{Theoretical model and hypotheses}

On the basis of the previous sections we propose three hypotheses about the relations between IT capability and innovativeness, innovativeness and firm performance, and IT competency and firm performance.

\section{IT capability and innovativeness}

Most ICT research is focused on the analysis of the factors influencing the adoption of ICT (Hollenstein, 2004, Bayo-Moriones and Lera-López, 2007), where the analyzed factors can be classified into three categories: factors related to the firms staff that will use IT, factors related to the firms characteristics and factors related to the business environment in which the firm operates (Ollo-López and AramendiaMuneta, 2012). The impact of IT on firms' innovativeness is very little analyzed, mainly as the impact of a particular technology to a particular category of innovation. OlloLópez and Aramendia-Muneta, (2012) analyzed the impact of IT on innovation and competitiveness by demonstrating that only the use of various IT does not affect the level of competitiveness, nor affect the level of innovation of the firm. In a small number of researches it has investigated not only the use of IT, but the existence of relating level of IT skills and its impact on innovation. In line with previous studies that have shown that IT alone will not result in increased innovation and competitiveness, but improvement IT skills along with IT processes and IT infrastructure will have positive impact on innovativeness, we propose the following hypothesis:

$\mathrm{Hl}$ : IT capability has a positive effect on the innovativeness.

Innovative capability and firm performance

"Innovation has become the industrial religion of the late 20th century. Business sees it as the key to increase profits and market share" (Baer and Frese, 2003). Innovations provide distinct advantages for the firm, helping it to achieve competitive advantages and superior business performance. Firms' ability to innovate is the most important determinant of the success (Calantone et al., 2002). Hurley and Hult (1998) recognized innovation as one of the key assumptions of competitive advantage and business performance of the company. On the basis of these statements, the proposed hypothesis is as follows:

$\mathrm{H}$ 2: Innovativeness has a positive effect on the firm performance.

\section{IT capability and firm performance}

During the past decade there has been a growing interest for the importance and value of information technology for the firms. A number of researches confirm the positive relationship between IT and business performance, while other fail to confirm the direct impact of IT on business performance. Pérez-López et. al. (2012) state that the reason for this inconsistency probably lies in the failure of the authors to recognize various organizational capacities as important intermediaries between IT and performance.

Thus, third hypothesis is:

H3: IT capability relates to the firm performance. 


\section{Methodology}

The first step was to choose population and objects to analyze. Considering that the topic is relevant for all business activities and that research will be done on the case of Bosnia and Herzegovina, which is relatively small market, it is decided to cover companies from all industries and business sectors. The classification of sectors is taken from the statistical classification of economic activities of the European Community - NACE.

In order to collect the data and for the purpose of this study, a questionnaire was distributed to the firms' management as an online survey using Limesurvey software using mailing lists. All questionnaires included a cover letter explaining the purpose of the study and assuring anonymity. Data was collected in the period of March-June of 2015.

A total of 531 questionnaires were completed and saved. Of these 531 questionnaires, 63 had a percentage of missing values over 80 percent, so we decided to eliminate them, following the complete case approach described in Hair et al. (2006). 468 questionnaires left for the analysis. The selected sample has characteristics of a convenient because firms are selected for the sample with respect to their availability and firms of each economic activity are included.

\section{Measures}

All the variables were measured on seven-point Likert scales ranging from 1 - strongly disagree to 7 - strongly agree.

IT capability (ITC). The measurement scale for IT capability was created using some of the items from the scales proposed by Tippins and Sohi (2003) and Kmieciak et al. (2012). To be precise, IT knowledge and IT infrastructure scales were taken from Tippins and Sohi (2003), while IT operations, due to the wording and easier translation were taken from Kmieciak et al. (2012). IT capability scale consisted of 17 items. An item parcelling strategy was employed for this scale. There are a number of advantages associated with the strategy of parcelling items, particularly when dealing with complex models and/or relatively small samples (Hau et al., 2004). The seventeen items representing each subscale of the ITC were parcelled into three indicators of a latent variable that reflected that subscale, namely IT knowledge (ITK), IT operations (ITO) and IT infrastructure (ITI).

Innovativeness (INNO). The measurement scale for innovativeness was adapted from Calantone et al. (2002) and it consisted of 3 items that reflect the extent to which a firm support ideas and creativity within firm.

Firms' performance (FP). This scale was adapted from Tseng (2014) and it consisted of 3 items measuring performance.

\section{Results and Discussion}

To test the proposed hypotheses of this study a structural equation model was estimated. The analysis for the present study was conducted using Lisrel 8.8 and utilizing the maximum likelihood method. Results are presented in the following table. 
Table 1

Model Testing Results

\begin{tabular}{|c|c|}
\hline Measures & Factor Loadings \\
\hline $\begin{array}{l}\text { IT capability } \\
\text { ITC = ITK } \\
\text { ITC = ITO } \\
\text { ITC = ITI }\end{array}$ & $\begin{array}{l}0.85 \\
0.87 \\
0.73\end{array}$ \\
\hline Innovativeness & \\
\hline $\begin{array}{l}\text { INNO }=I N N O 1 \\
I N N O=I N N O 2 \\
I N N O=I N N O 3\end{array}$ & $\begin{array}{l}0.85 \\
0.90 \\
0.85\end{array}$ \\
\hline $\begin{array}{l}\text { Firms performance } \\
\text { FP }=\text { FP } 1 \\
\text { FP }=\text { FP2 } \\
\text { FP }=\text { FP3 }\end{array}$ & $\begin{array}{l}0.94 \\
0.85 \\
0.84\end{array}$ \\
\hline
\end{tabular}

Source: Authors

As the table shows, the overall model demonstrates an acceptable fit. Indices NNFI, CFI, RMSEA and GFI are at acceptable levels.

Further, the results show that there is a positive and significant relation between IT capability and innovativeness, as it is suggested with $\mathrm{Hl}: \beta=0.49, t=9.59, \mathrm{p}<0.01$. Also, the results show that there is a positive and significant relation between innovativeness and firms performance: $\beta=0.25, t=4.38, p<0.01$, and least, but still significant relation between ITC and FP: $\beta=0.15, t=2.55, p<0.01$.

Our findings provide empirical support for the relation between IT capability and innovativeness. IT capability facilitates innovativeness and indirectly affects firms' performance. Also, ITC directly impacts firms performance, but indirect impact via innovativeness is more significant. This result is consistent with the results of previous work in the literature (Tippins and Sohi, 2003).

\section{Conclusion}

This paper proposes and tests a model that establishes an integrative view of the links between IT capability, innovativeness and performance. It proposes a contribution to IT research by clarifying the mediating role played by innovativeness in creating and capturing value from information technology. In order to achieve superior business performance and take full advantages of IT possibilities, it is important for managers to understand the role of innovativeness and proposed relations with ITC and performance.

\section{References}

1. Baer, M., Frese, M. (2003), "Innovation is not enough: climates for initiative and psychological safety, process innovations, and firm performance", pp. 45-68.

2. Mitchell, R. (2008), "Resource-Based Theory: Creating and Sustaining Competitive Advantage", Edited by J.B. Barney and D.N Clark Oxford University Press, Oxford, Paperback, 2007; 316 pages, ISBN 978-019-927769-8, Journal of Public Affairs, Vol. 8, pp. 309-313, doi: 10.1002/pa.303 
3. Barney, J.B. (1991), "Firm Resources and Sustained Competitive Advantage", Journal of Management, Vol. 17 No. 1, pp. 99-121.

4. Bayo-Moriones, A., Lera-López, F. (2007), "A firm-level analysis of determinants of ICT adoption in Spain", Technovation, Vol. 27 No. 6-7, pp. 352-366.

5. Calantone, R.J., Cavusgil, S.T., Zhao, Y. (2002), "Learning orientation, firm innovation capability, and firm performance", Industrial Marketing Management, Vol. 31 No. 6, pp. 515-524.

6. Chakravarty, A., Grewal, R., Sambamurthy, V. (2013), "Information technology competencies, organizational agility, and firm performance: Enabling and facilitating roles. Information Systems Research", Vol. 24 No. 4, pp. 976-997.

7. Chen, C.-J., Huang, J.-W., Hsiao, Y.-C. (2010), "Knowledge management and innovativeness: The role of organizational climate and structure", International Journal of Manpower, Vol. 31 No. 8, pp. 848-870.

8. Crawford, J., Leonard, L.N.K., Jones, K. (2011), "The human resource's influence in shaping IT competence", Industrial Management \& Data Systems, Vol. 111 No. 2, pp. $164-$ 83.

9. Dibrell, C., Craig, J.B., Neubaum, D.O. (2014), "Linking the formal strategic planning process, planning flexibility, and innovativeness to firm performance", Journal of Business Research, Vol. 67 No. 9, pp. 2000-2007.

10. Hair, J.F., Black, W. C., Babin, B.J., Anderson, R.E., Tatham, R.L. (2006) "Multivariate data analysis" (6th ed.), Uppersaddle River: Pearson Prentice Hall.

11. Hau, K.-T., Marsh, H.W. (2004), "The use of item parcels in structural equation modelling: non-normal data and small sample sizes", The British Journal of Mathematical and Statistical Psychology, Vol. 57 No. 2, pp. 327-351.

12. Hollenstein, H. (2004), "Determinants of the adoption of Information and Communication Technologies (ICT)", Structural Change and Economic Dynamics, Vol. 15 No. 3, pp. 315342.

13. Hurley, R.F. Hult, G.T.M. (1998), "Innovation, market orientation, and organizational learning: an integration and empirical examination", Journal of Marketing, Vol. 62 No. 3, pp. $42-54$.

14. Kmieciak, R., Michna, A., Meczynska, A. (2012), "Innovativeness, empowerment and IT capability: evidence from SMEs", Industrial Management \& Data Systems, Vol. 112 No. 5, 707-728.

15. Lee, T.-S., Tsai, H.-J. (2005), "The effects of business operation mode on market orientation, learning orientation and innovativeness", Industrial Management \& Data Systems, Vol. 105 No. 3, pp. 325-348.

16. Mithas, S., Ramasubbu, N., Sambamurthy, V. (2011), "How Information Management Capability Influences Firm Performance". MIS Quarterly, Vol. 35 No.1, pp. 137-A15.

17. Ollo-López, A., Aramendía-Muneta, M.E. (2012), "ICT impact on competitiveness, innovation and environment". Telematics and Informatics, Vol. 29 No. 2, pp. 204-210.

18. Pérez-López, S. Alegre, J. (2012), "Information technology competency, knowledge processes and firm performance", Industrial Management \& Data Systems, Vol. 112 No. 4, pp. 644-662.

19. Tippins, M.J., Sohi, R.S. (2003), "IT competency and firm performance: Is organizational learning a missing link?", Strategic Management Journal, Vol. 24 No. 8, pp. 745-761.

20. Tseng, S.-M. (2014), "The impact of knowledge management capabilities and supplier relationship management on corporate performance", International Journal of Production Economics, Vol. 154, pp. 39-47.

21. Wernerfelt, B. (1984), "A Resource-based View of the Firm", Strategic Management Journal, Vol. 5, pp. 171-80.

22. Wu, F. et al. (2006), "The impact of information technology on supply chain capabilities and firm performance: A resource-based view", Industrial Marketing Management, Vol. 35 No. 4, pp.493-504. 


\section{About the authors}

Lejla Turulja is a Senior Teaching Assistant at the School of Economics and Business Sarajevo, B\&H. She is a PhD student at the SEBS. She teaches Business Informatics, MIS, MIT, ICT and Knowledge Management. Her areas of research include IT, firms' capabilities, innovativeness, knowledge management, information management. Author can be contacted at lejla.turulja@efsa.unsa.ba

Nijaz Bajgorić is a Professor of Business Computing and Information Technology Management at the School of Economics and Business Sarajevo, B\&H. He has a PhD from the University of Sarajevo. He teaches and conducts research in information technology, business computing, information technology management and operating systems. He has published papers in the following peer-reviewed journals: International Journal of Enterprise Information Systems, Cybernetics, Information Management and Computer Security, Information Systems Management, Industrial Management and Data Systems etc., and has authored and co-authored chapters in the edited books published by: Elsevier Science, Kluwer Academic Publisher, CRC Press and Auerbach Publications. Author can be contacted at nijaz.bajgoric@efsa.unsa.ba 